\section{MERRILL'S 'TREATISE ON ROCKS.'}

To THE Editor of ScIEnce: In animadverting on the defective English of Professor Merrill's 'Treatise on Rocks,' etc., in your current number, Mr. Woodworth says: "In the case of other quotations it is sometimes doubtful as to which author the work in a certain district is to be referred" (page 996). Will the author of this sentence kindly express his idea in German or French or Chinook, and thereby oblige half a dozen readers who find themselves unable to grasp his exact meaning?

W J MCGEe.

Washington, D. C., June 26, 1897.

THE TRIAL OF THE CROSSLEY REFLECTOR OF THE LICK OBSERVATORY.

A MATTER relating to work at the Lick Observatory (with reference to the trial of the three-foot reflecting telescope presented to us by Mr. Crossley, of England, in 1895) has lately been discussed in newspaper press-dispatches in rather a one-sided fashion. I desire to say that the questions involved have been passed upon by the Regents of the University of California, who have, unanimously, approved my action. The decisions of the Regents have not been spoken of in press-dispatches, which is my reason for writing this note.

Edward S. Holden.

The Lick Observatory, June 21, 1897.

\section{SCIENTIFIC LITERATURE.}

Our Native Birds of Song and Beauty. By Henry

NeHrling. Published by George Brumder, Milwaukee. Vol. II., 4. Pp. 453; 18 colored plates. Complete work in 16 parts, $\$ 16$; bound in 2 vols., library binding, $\$ 18$; handsome dark leather binding, $\$ 22$.

The second complete volume of this admirable work, some of the separate parts of which have been already noticed in these pages, has now been issued to subscribers. The two volumes make a handsome addition to any library and should be in the possession of all lovers of birds. The work contains no technical matter, and little effort has been made to incorporate the latest facts bearing on the geographic distribution of the various species, the aim being to supply trustworthy accounts of the life histories of the birds in relation to their environment and in their relations to man. Mr. Nehrling has the instincts and sympathies of a naturalist. He is evidently a botanist and musician as well as an ornithologist, and his descriptions of bird life are generally woven in with pictures of shady ravines and forest glades or flowery dells where the birds and plants and landscape are seen together as they are in nature. His residence in widely separated localities-Wisconsin, Missouri, Texas and Floridahas enabled him to become familiar with a large proportion of the birds he treats, and his personal knowlege is supplemented by copious extracts from the writings of others. Special emphasis is given to economic relations and breeding habits.

As stated in notices of the earlier parts, the illustrations, all of which are colored, show the birds in natural surroundings and are of two kinds: plates of single species, mostly by Robert Ridgway; and mixed plates, by Mützel and Göring. Some of Mr. Ridgway's plates of single species are among the most charming bird pictures I have ever seen. Those of special excellence in the present volume are the Black Rosy Finch (Leucosticte atrata) and Dickcissel (Spiza americana)-the former on a mountain top, the latter in a clover field. Three of the mixed plates by Mützel are worthy of special mention; Plate XXI, a group of showy winter birds-the Pine Bullfinch, White-winged Crossbill, Redpoll, Evening Grosbeak, Nuthatch and Chickadee-in the top of a snow-covered spruce; Plate XXVIII, the Blue Grosbeak and three species of Passerina-the Indigo Bird, Painted Bunting and Lazuli Finch; Plate XXXVI, six species of brilliantly colored Woodpeckers.

Even in the mixed plates the attempt has been made to group the species in appropriate surroundings, and much pains has been taken with the landscape and vegetation. Thus, Göring's picture of the Scissor-tailed Flycatcher, Green Jay and Verdin shows these birds (and one or two others) among cactuses, flowering agaves, and aborescent yuccas with a barren range of desert mountains in the background.

Although the plates are of uneven merit, even the poorest are sufficiently good to serve the purpose of identification and will be most 